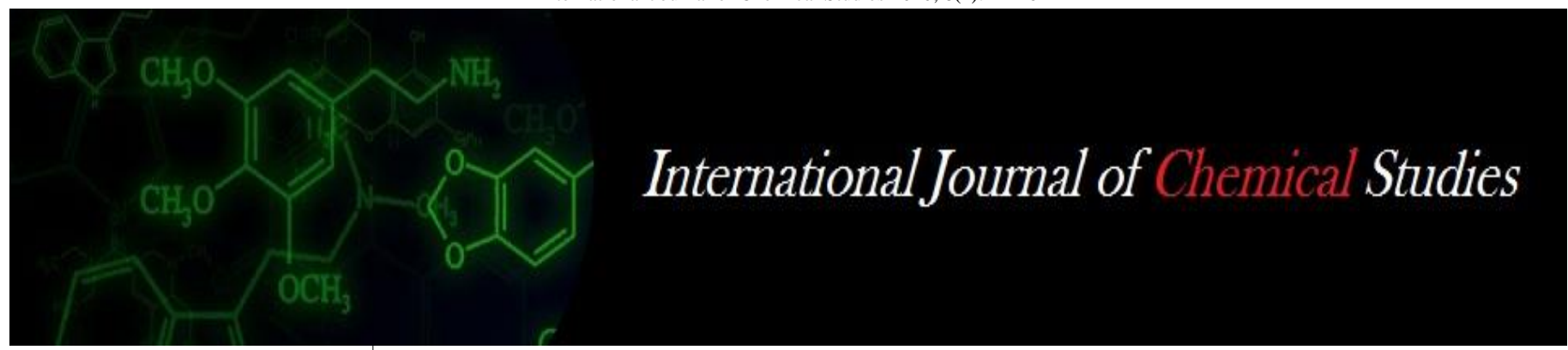

P-ISSN: 2349-8528

E-ISSN: 2321-4902

www.chemijournal.com

IJCS 2020; 8(4): 14-16

(C) 2020 IJCS

Received: 09-05-2020

Accepted: 12-06-2020

Dr. Archana Jyoti

Associate Professor,

Department of Chemistry,

S.S. Khanna Girls Degree

College, Prayagraj,

Utter Pradesh, India

\section{Synthesis and antiviral activity of 1-(n-substituted amino acetyl)-2-(5-substituted phthalimidomethyl) benzimidazoles}

\section{Dr. Archana Jyoti}

DOI: https://doi.org/10.22271/chemi.2020.v8.i4a.10151

\section{Abstract}

Phthalic anhydride and 3-Nitro Phthalic anhydride were reacted with 2-aminomethyl benzimidazole in pyridine to give 2- (5-substituted phthalimidomethyl) bezimidazoles. These benzimidazoles were refluxed with chloroacetyl chloride in dry benzene followed by reaction with different secondary amines to give 1-(N-substituted amino acetyl)-2-(5-substituted phthalimidomethyl) benzimidazoles. Antiviral activity of these compounds was studied against Ranikhet Disease Virus (RDV) and Vaccinia Virus (VV). Some of these compounds have been found to be active against RDV.

Keywords: benzimidazoles, phthalic anhydride, ranikhet disease virus, vaccinia virus

\section{Introduction}

A number of compounds containing benzimidazole nucleus have been found to possess various antiviral activities ${ }^{[1,2]}$. Various benzimidazole derivatives have been found to be active against Vaccinia Virus ${ }^{[3]}$. Some other benzimidazole derivatives have been found to be associated with antiviral activity against Ranikhet Disease Virus ${ }^{[4]}$. These results encouraged the author to synthesise1-(N-substituted amino acetyl)-2-(5-substituted phthalimidomethyl) benzimidazoles and to study their pharmacological action.

Scheme

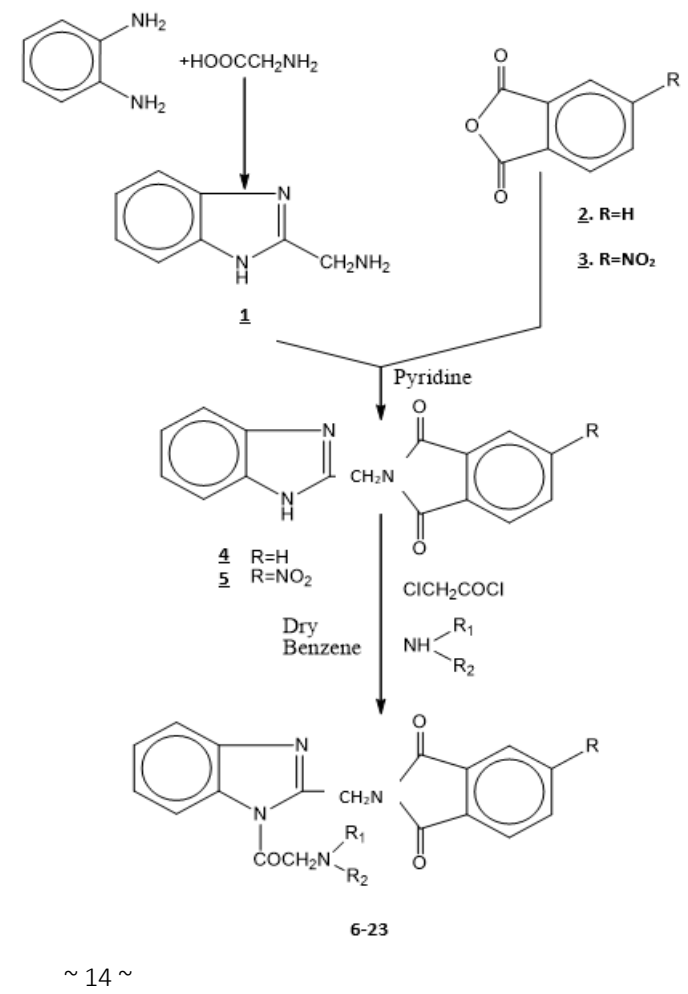




\section{Methodology}

3-nitrophthalic anhydride (3) was prepared according to the method reported earlier ${ }^{[5]}$.

To phthalic anhydride (2) (25 gm) and concentrated sulphuric acid $(32.5 \mathrm{ml})$ fuming nitric acid $(10.5 \mathrm{ml})$ was added at such a rate so as to maintain the temp. At $100-100^{\circ} \mathrm{C}$. Then conc. nitric acid $(45 \mathrm{ml})$ was added to the whole mass. The mixture was heated on water bath with stirring for $2 \mathrm{hrs}$. It was kept overnight and then poured into cold water. The resultant mixture of 3-and 4-nitrophthalic acid was filtered and the wet cake was dissolved in hot water so as to dissolve a large amount of 4-nitro acid. It was then filtered and the hot filtrate was stirred mechanically until crystallization commenced. Then it was left overnight and filtered so as to obtain 3nitrophthalic acid. m. p. $210-212^{\circ} \mathrm{C}\left[216-218^{0}\right]^{4}$, yield $70 \%$.

To 3-nitrophthalic acid (0.01 mile), acetic anhydride $(65 \mathrm{ml})$ was added. It was heated gently to boiling till a clear solution was obtained and then heated for about $10 \mathrm{~min}$. more. The hot mixture was poured into a large porcelain dish and was allowed to cool. The crystalline mass was grinded thoroughly in a mortar and filtered at pump. 3-nitrophthalic anhydride thus obtained was again grinded with $50 \mathrm{ml}$ of dried ether and finally recrystallized from benzene.
3- m. p. $161^{\circ} \mathrm{C}\left[163-164^{\circ} \mathrm{C}\right]^{4}$ yield $70 \%$.

2-(5-substituted phthalimidomethyl) benzimidazoles (4\&5) 2-aminomethyl benzimidazole (1) (0.01 mole) and an appropriate phthalic anhydride $(2 \& 3)$ (0.01 mole) were refluxed in $10 \mathrm{ml}$ of pyridine for 5-6 hrs. Excess pyridine was distilled off and the contents were poured in ice cold water containing few drops of conc. hydrochloric acid. The solid, so obtained was washed with water, dried and recrystallized from methanol.

4. m. p. $240^{\circ} \mathrm{C}\left[242-244^{0} \mathrm{C}\right]^{5}$ yield $70 \%$. $(\mathrm{R}=\mathrm{H})$

5. m. p. $270^{\circ} \mathrm{C}\left[275^{\circ} \mathrm{C}\right]^{5}$ yield $70 \%$. $\left(\mathrm{R}=\mathrm{NO}_{2}\right)$

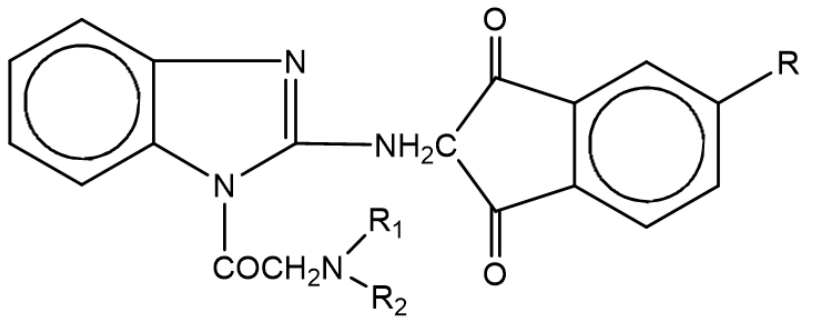

Table 1: Characterisation data of 1-(N-substituted amino acetyl)-2-(5 substituted phthalimidomethyl) benzimidazoles (6-23)

\begin{tabular}{|c|c|c|c|c|c|c|c|c|c|}
\hline \multirow{2}{*}{$\begin{array}{c}\text { Compd. } \\
\text { No. }\end{array}$} & \multirow{2}{*}{$R_{1} \ldots-\ldots-$ N---- $R_{2}$} & \multirow{2}{*}{ Molecular formula } & \multirow{2}{*}{ M.P. ${ }^{0} \mathrm{C}$} & \multicolumn{3}{|c|}{ Analysis: Calculated } & \multicolumn{3}{|c|}{ Analysis: Found } \\
\hline & & & & $\mathbf{C}$ & $\mathbf{H}$ & $\mathbf{N}$ & $\mathbf{C}$ & $\mathbf{H}$ & $\mathbf{N}$ \\
\hline \multicolumn{10}{|c|}{$\mathbf{R}=\mathbf{H}$} \\
\hline 6 & Diethanolamino & $\mathrm{C}_{22} \mathrm{H}_{22} \mathrm{~N}_{4} \mathrm{O}_{5}$ & 192 & 62.56 & 5.21 & 13.27 & 62.14 & 5.14 & 13.20 \\
\hline 7 & Morpholino & $\mathrm{C}_{22} \mathrm{H}_{20} \mathrm{~N}_{4} \mathrm{O}_{4}$ & 216 & 65.35 & 4.95 & 13.86 & 65.29 & 4.85 & 13.72 \\
\hline 8 & N-ethylanlino & $\mathrm{C}_{26} \mathrm{H}_{22} \mathrm{~N}_{4} \mathrm{O}_{3}$ & 190 & 71.23 & 5.02 & 12.78 & 71.03 & 5.09 & 12.52 \\
\hline 9 & N-methylanilino & $\mathrm{C}_{25} \mathrm{H}_{20} \mathrm{~N}_{4} \mathrm{O}_{3}$ & 170 & 70.75 & 4.72 & 13.21 & 70.72 & 4.52 & 13.01 \\
\hline 10 & $\mathrm{~N}$-phenylpiperazino & $\mathrm{C}_{28} \mathrm{H}_{25} \mathrm{~N}_{5} \mathrm{O}_{3}$ & 215 & 70.15 & 5.22 & 14.61 & 70.10 & 5.20 & 14.60 \\
\hline 11 & $\mathrm{~N}$-methylpiperazino & $\mathrm{C}_{23} \mathrm{H}_{23} \mathrm{~N}_{5} \mathrm{O}_{3}$ & 215 & 66.18 & 5.52 & 16.79 & 66.07 & 5.07 & 16.70 \\
\hline 12 & Diethylamino & $\mathrm{C}_{22} \mathrm{H}_{22} \mathrm{~N}_{4} \mathrm{O}_{3}$ & 235 & 67.69 & 5.64 & 14.36 & 67.09 & 5.03 & 14.30 \\
\hline 13 & Piperidino & $\mathrm{C}_{23} \mathrm{H}_{22} \mathrm{~N}_{4} \mathrm{O}_{3}$ & 226 & 68.66 & 5.47 & 13.93 & 68.60 & 5.42 & 13.85 \\
\hline 14 & Diphenylamino & $\mathrm{C}_{30} \mathrm{H}_{22} \mathrm{~N}_{4} \mathrm{O}_{3}$ & 240 & 74.07 & 4.53 & 11.52 & 74.02 & 4.50 & 11.38 \\
\hline \multicolumn{10}{|c|}{$\mathbf{R}=\mathbf{N O}_{2}$} \\
\hline 15 & Diethanolamino & $\mathrm{C}_{22} \mathrm{H}_{21} \mathrm{~N}_{5} \mathrm{O}_{7}$ & 206 & 56.53 & 4.49 & 14.99 & 56.08 & 4.52 & 14.98 \\
\hline 16 & Morpholino & $\mathrm{C}_{22} \mathrm{H}_{19} \mathrm{~N}_{5} \mathrm{O}_{6}$ & 213 & 58.79 & 4.23 & 15.59 & 58.54 & 4.21 & 15.32 \\
\hline 17 & N-ethylanilino & $\mathrm{C}_{26} \mathrm{H}_{21} \mathrm{~N}_{5} \mathrm{O}_{5}$ & 222 & 64.59 & 4.35 & 14.49 & 64.58 & 4.02 & 14.04 \\
\hline 18 & N-methylanilino & $\mathrm{C}_{25} \mathrm{H}_{19} \mathrm{~N}_{5} \mathrm{O}_{5}$ & 209 & 63.97 & 4.05 & 14.92 & 63.02 & 4.02 & 14.62 \\
\hline 19 & Diethylamino & $\mathrm{C}_{22} \mathrm{H}_{21} \mathrm{~N}_{5} \mathrm{O}_{5}$ & 202 & 60.69 & 4.83 & 16.09 & 60.09 & 4.87 & 16.25 \\
\hline 20 & Piperidino & $\mathrm{C}_{23} \mathrm{H}_{21} \mathrm{~N}_{5} \mathrm{O}_{5}$ & 185 & 61.74 & 4.69 & 15.66 & 61.20 & 4.62 & 15.62 \\
\hline 21 & N-phenylpiperazino & $\mathrm{C}_{28} \mathrm{H}_{24} \mathrm{~N}_{6} \mathrm{O}_{5}$ & 210 & 64.12 & 4.58 & 16.03 & 64.05 & 4.35 & 16.00 \\
\hline 22 & $\mathrm{~N}$-methylpiperazino & $\mathrm{C}_{23} \mathrm{H}_{22} \mathrm{~N}_{6} \mathrm{O}_{5}$ & 226 & 59.74 & 4.76 & 18.18 & 59.52 & 4.71 & 18.08 \\
\hline 23 & Diphenylamino & $\mathrm{C}_{30} \mathrm{H}_{21} \mathrm{~N}_{5} \mathrm{O}_{5}$ & 240 & 67.79 & 3.95 & 13.18 & 67.10 & 3.85 & 13.05 \\
\hline
\end{tabular}

Yields ranged from $65-70 \%$.

\section{1-(N-substituted amino acetyl)-2-(5-substituted phthalimidomethyl) benzimidazoles (6-23)}

2-(5-substituted phthalimidomethyl) benzimidazole (4-5) (0.01 mole) was refluxed with chloroacetyl chloride (0.1 mole) in dry benzene for 8-10 hrs. Thereafter, an appropriated secondary amine (0.01 mole) was added to the reaction mixture and it was again refluxed on water bath for $6 \mathrm{hrs}$. Excess of benzene was distilled off and solid obtained was filtered and recrystallised from DMSO. Compounds 6-23, thus synthesized are listed in Table-1.

IR (KBr): Compounds showed IR spectral bands at 2780$2770\left(\mathrm{~N}-\mathrm{CH}_{2}\right), 1725$ (acyclic $\mathrm{C}=\mathrm{O} .1700-1690($ Cyclic $\mathrm{C}=\mathrm{O})$, 1610-1600 $(\mathrm{C}=\mathrm{N}), 1540-1535$ and 1315-1310 $\left(\mathrm{NO}_{2}\right)$,

PMR $\left(\mathrm{CDC1}_{3}\right)$ : Compound 13: 1.42-1.54 (m, 6H, C-CH $)_{2}$, 2.60-2.74 (m, 6H, N-CH$), 3.80-3.82\left(\mathrm{~s}, 2 \mathrm{H}, \mathrm{N}-\mathrm{CH}_{2}-\mathrm{C}=\mathrm{O}\right)$ and 7.18-.85 (m 8H, Ar-H).

\section{Antiviral activity against RDV}

Compounds were tested against RDV in a stationary culture of minced chorioallantoic membrane of chick embryo. The strain of the Ranikhet Disease Virus was the same as employed by Babber and Dhar ${ }^{[7]}$. Chorioallantoic membrane (CAM) of 10 days old chick embryos were taken and the culture prepared according to the method of Babbar ${ }^{[8,9]}$. The soluble compounds were dissolved in a nutrient fluid and the insoluble compounds were suspended in it in the presence of Tween 80 and the $\mathrm{pH}$ adjusted to 7.2 before sterilization. The solutions were then sterilized by autoclaving at $15 \mathrm{lbs}$ pressure for $15 \mathrm{~min}$. Two fold serial dilutions were then made and $1 \mathrm{ml}$ of each dilution added to each of the test tubes containing the CAM culture. The dilution of a compound causing toxic symptoms in $50 \%$ of the CAM culture was taken as the end point. 
The highest nontoxic dose was given to each culture along with the virus (0.64 HA units/ml). Virus multiplication was measured by the haemagglutination (HA) titre (mean of $\log _{2}$ ) of the culture collected after $48 \mathrm{hrs}$ of incubation at $37^{\circ} \mathrm{C}$. Inhibition in virus multiplication was obtained by subtracting this titre from that of the control. The mean difference (d) of 2 $\log _{2}$ HA units is significant at $50 \%$ or more than $50 \%$ level.

\section{Antiviral activity against vaccinia virus}

All the eighteen compounds were also tested ${ }^{[10]}$ against Vaccinia Virus on chick embryo fibroblast monolayers. 0.05 $\mathrm{mg} / \mathrm{ml}$ compound was given along with Vaccinia virus (50 $\mathrm{p} / \mathrm{ml}$ ) and incubated at $37^{\circ} \mathrm{C}$ for $72 \mathrm{hrs}$. After $72 \mathrm{hrs}$ the monolayers were strained and the numbers of plaques/monolayers were counted. The activity was calculated by the formula $\mathrm{C}-\mathrm{T} / \mathrm{C} \times 100$.

Table 2: Antiviral Activity of Compounds 6-23 against RDV

\begin{tabular}{|c|c|c|c|}
\hline $\begin{array}{c}\text { Compound. } \\
\text { No. }\end{array}$ & $\begin{array}{c}\text { Percent inhibition } \\
\text { against RDV }\end{array}$ & $\begin{array}{c}\text { Compound. } \\
\text { No. }\end{array}$ & $\begin{array}{c}\text { Percent inhibition } \\
\text { against RDV }\end{array}$ \\
\hline 6 & 0 & 15 & 30 \\
\hline 7 & 60 & 16 & 10 \\
\hline 8 & 40 & 17 & 0 \\
\hline 9 & 30 & 18 & 60 \\
\hline 10 & 40 & 19 & 46 \\
\hline 11 & 20 & 20 & 30 \\
\hline 12 & 40 & 21 & 36 \\
\hline 13 & 60 & 22 & 0 \\
\hline 14 & 40 & 23 & 0 \\
\hline
\end{tabular}

Compounds were tested at the dose of $0.1 \mathrm{mg} / \mathrm{ml}$ against 0.064 units/ml of RDV

\section{Results and discussion}

Eighteen benzimidazoles (6-23, Table-1) were tested against RDV and Vaccinia virus. Results of testing against RDV are recorded in Table-2.These results indicate that compounds 7 , 13 and 18 were active against the virus. Compounds 6, 17, 22 and 23 possessed no activity while other compounds showed $10-46 \%$ inhibition against the virus.

From these results, presented in Table-2, it appears that compounds have been found to be more active when $\mathrm{R}=\mathrm{H}$, rather than when $\mathrm{R}=-\mathrm{NO}_{2}$. Also, substitution of dialkyl amino group by morpholino, piperidino and $\mathrm{N}$-methyl anilino groups increases the antiviral activity of compounds, whereas substitution by diethanolamino, N-ethylanilino and N-phenyl piperazino groups considerably reduces the activity of compounds.

Compounds 6-23 were also screened against Vaccinia virus. However no compound was found to be active against this virus. Author recommends broad range research in this field, as the some viruses may cause cancer ${ }^{[11]}$. Now it is possible to reactivate the tumor suppressor genes by using natural products ${ }^{[12]}$, which is a good sign for human health.

\section{References}

1. Afshan Kanwal, Matloob Ahmad, Sana Islam, Syed Ali, Raza Naqvi, Muhammd Jawwad et al. saif; Pharmaceutical Chemistry Journal. 2019; 53:179-187.

2. Michele Toneli, Matteo Simone, Bruno Tasso, Federica Novelii. Bioorganic and medicinal Chemistry. 2010; 18(8):2937-53.

3. Sharma Deepika, Narsimhan Balasubramanian, Kumar Pradeep, Judge Vikramjeet, Narang Rakesh, Erik De et al. Clerk; Journal of Enzyme Inhibition and Medicinal Chemistry, 2009, 1161-1168.
4. Singh VA. Synthesis of Benzimidazoles and Related Hetero Systems as Potential Antiviral agents Thesis, Department of Chemistry, Lucknow chemistry, 1985, 123.

5. Vogel AI. Text Book of practical Organic Chemistry, Longman Group Limited Ed III 966, 1971.

6. Mishra VS, Shah P, Saxena VK. Indian J Pharm. Sci., 1982, 44(4).

7. Babbar OP, Dhar MM. J Sci. Ind. Res. 1956; 15c:249.

8. Babbar OP. J Sci. Ind. Res. 1961; 20c:216.

9. Babbar OP, J Sci. Ind. Res. 1961; 20c:232.

10. Babbar OP, Chowdhury BL, Singh MP, Khan SK, Bajpai S. Indian J Exp. Biol. 1970; 8:204-12.

11. Masroor MS, Parween S, Salim M, Prajapati IP. A note on hepatitis viruses causing cancer in human. International Journal of Biological Innovations. 2020; 2(2):126-28.

12. Saha D, Vaishnav N, Ahsan Z, Rani N, Mathur R, Jha AK. Reversal of hypermethylation and reactivation of Tumor Suppressor Genes due to natural compounds in Breast Cancer Cells. International Journal of Biological Innovations. 2020; 2(1):63-75. 